\title{
RÁDIÓTÁVCSŐ-HÁLÓZATOK KÖZÖS ÉGBOLT ALATT
}

\section{RADIO TELESCOPE NETWORKS UNDER ONE SKY}

\author{
Gabányi Krisztina Éva \\ PhD, MTA-ELTE Extragalaktikus Asztrofizikai Kutatócsoport, Csillagászati és Földtudományi Kutatóközpont \\ Konkoly Thege Miklós Csillagászati Intézet, Budapest \\ krisztina.g@gmail.com
}

\begin{abstract}
ÖSSZEFOGLALÁS
Jelenleg rádiótartományban végzett mérésekkel érhető el a lehető legfinomabb szögfelbontás a csillagászatban, mivel ebben a hullámhossztartományban lehetőség van a fizikailag nagy távolságra lévő antennák hálózatba kötésével az interferometria megvalósítására. Az alábbiakban bemutatom a rádióinterferometria működési elvét és a legismertebb hálózatokat, amelyek elsöprő többsége tudományos pályázatok útján nyitott az egész csillagász (illetve akár a bővebb tudományos) közösség előtt. A rádióantenna-rendszerek különböző tulajdonságait egy példán keresztül, a nagy kozmológiai távolságban megfigyelhető rádiósugárzó aktív galaxismagok segítségével illusztrálom.
\end{abstract}

\section{ABSTRACT}

Currently, radio astronomy provides the highest angular resolution in astronomy using a technique called interferometry, when antennas located at large distances observe the same celestial source and work together as an array. In the following, I present the basic concept of radio interferometry, and introduce the most commonly used interferometer networks. Almost all of those are open to the entire scientific community; submitted observing proposals are judged only by their scientific merit. I illustrate the different characteristics of the radio interferometer networks through the example of studying distant radio-emitting active galactic nuclei.

Kulcsszavak: rádiócsillagászat, rádióinterferométeres hálózatok, rádiósugárzó aktív galaxismagok

Keywords: radio astronomy, radio interferometry networks, radio-emitting active galactic nuclei

A rádiócsillagászatban az elektromágneses tartomány hosszú hullámhosszú (deciméteres, centiméteres, milliméteres, szubmilliméteres) sugárzását figyeljük meg. Mivel a felbontóképesség a hullámhossztól és a múszerünk átméröjétöl függ, könnyen látható, hogy a csillagászat egyéb ágaihoz képest a rádiócsillagá- 
szat komoly hátránnyal indul. Például ahhoz, hogy centiméteres hullámhosszakon ugyanolyan szögfelbontást érjünk el, amilyenre a szemünk az optikai tartományban képes, mintegy száz méter átméröjü rádióantennára van szükségünk. Mégis, jelenleg a rádiócsillagászat képes a legfinomabb szögfelbontást elérni; ugyanis könnyedén kihasználhatjuk az elektromágneses sugárzás hullámtermészetét, és rádióantennákat hálózatba kapcsolva, interferométerrel végezhetünk méréseket. A rádióinterferométer felbontását a müszer átméröje helyett a leghosszabb bázisvonal, az antennák közötti legnagyobb távolság határozza meg. Míg egyetlen mozgatható müszer felbontóképességét korlátozza a maximálisan elérhető, nagyjából százméteres átmérő (ennél nagyobb szerkezet ugyanis összeomlana a saját súlya alatt), az interferométeres hálózatban részt vevő antennákat egymástól nagy távolságban akár különböző kontinensekre is lehet telepíteni, illetve müholdakon elhelyezett antennák bevonásával a felbontásnak még a Föld mérete sem szabhat határt.

Számos rádióinterferométer-hálózat müködik a Földön. Az egyik legismertebb az amerikai Új-Mexikó államban található Karl G. Jansky Very Large Array (VLA). A VLA 27 antennája egy Y-t formáló alakban helyezkedik el. Az egyes karok mentén az antennákat síneken mozgatva négy különböző konfiguráció valósítható meg. Az elérhető leghosszabb bázisvonal $36 \mathrm{~km}$. A VLA jellemzően cm-es hullámhosszakon végez megfigyeléseket, $6 \mathrm{~cm}$-en például az általa biztosított legfinomabb szögfelbontás 0,33 ívmásodperc. Az angliai enhanced Multi Element Remotely Linked Interferometer Network (e-MERLIN) hét antennája jóval messzebb helyezkedik el egymástól, a leghosszabb bázisvonal $217 \mathrm{~km}$, így $6 \mathrm{~cm}$-es hullámhosszon 50 ezredívmásodperces szögfelbontást biztosít. Ez körülbelül akkora, mint az optikai tartományban földfelszínen müködő egyedi teleszkóppal elérhető legfinomabb szögfelbontás, illetve a Föld körüli pályán keringő Hubble-ürtávcső felbontóképessége.

Még távolabbra helyezett antennák hálózatba kötésével valósítható meg a nagyon hosszú bázisvonalú interferometria (very long baseline interferometry, VLBI) néven ismert technika. Ekkor az akár külön kontinenseken lévő antennák figyelik ugyanazt az égi forrást, a rádiójeleket adathordozókra rögzítik, majd később egy számítóközpontban (a korrelátorban) állítják elő az interferenciát. Az adatátviteli technika fejlődése lehetővé tette, hogy manapság a hálózat elemeit nagy sebességủ adattovábbítást lehetővé tevő, nagy sávszélességủ optikai kábelekkel kössék össze, ily módon az adatok egyböl a korrelátorba érkezhetnek (nem kell repülővel, hajóval stb. szállítani az adathordozókat), és - némely hálózat esetében - akár valós idejü korrelálásra is lehetőség nyílik. VLBI-technikát valósít meg például az amerikai Very Long Baseline Array (VLBA) és az Európai VLBI Hálózat $(E V N)$ is, az utóbbinál lehetőség van valós idejü korrelálásra is.

A VLBA tíz egyforma rádióantennából áll, amelyek az Amerikai Egyesült Államok területén helyezkednek el. A leghosszabb bázisvonalat, 8000 km-t, a 
karibi Virgin-szigeteki Saint Croix- és a hawaii Mauna Kea-antennák között találjuk. Így 6 cm-es hullámhosszon 1,6 ezredívmásodperces felbontást érhetünk el, kelet-nyugati irányban. A VLBA dedikált VLBI- hálózat, ami azt jelenti, hogy kizárólag hálózatként müködik, az egyes rádiótávcsövek nem különálló müszerek, nem végeznek egyedi méréseket. Az EVN esetében nem ez a helyzet. Az ebben a hálózatban részt vevő antennák különböző országok intézeteihez tartoznak. Az intézetek vezetői által irányított konzorcium állapodik meg arról, hogy az év adott időszakaiban az antennák mint a hálózat részei fognak múködni, és nem mint egyedi müszerek. Az EVN három, egyenként 21 napos időszakban hagyományos megfigyeléseket folytat, míg havonta-kéthavonta néhány napos, valós idejü korrelálást biztosító megfigyelésre is lehetőség van.

Nevével ellentétben az EVN-hez nemcsak európai, hanem ázsiai és afrikai antennák is tartoznak (1. ábra). Így $6 \mathrm{~cm}$-es hullámhosszon a VLBA-hoz hasonló másfél ezredívmásodperces szögfelbontást kelet-nyugati (kínai és európai antennák között) és észak-déli (európai és dél-afrikai antennák között) irányban is biztosít. Emellett az EVN érzékenysége jobb, mint az amerikai hálózaté. Ez a megfigyelésekben részt vevő nagy átmérőjü - például a 100 m-es effelsbergi, a 65 m-es sanghaji és 64 m-es szardíniai - antennáknak köszönhető. (Összehasonlításképpen, a VLBA antennái 25 m átmérőjüek.) A két hálózat együtt is használható mint egyetlen globális interferométer. Emellett az EVN-hez csatlakoztatva lehetőség van ausztrál, dél-koreai és egyedi amerikai antennákkal is kiegészíteni az elérhető bázisvonalak hálózatát.

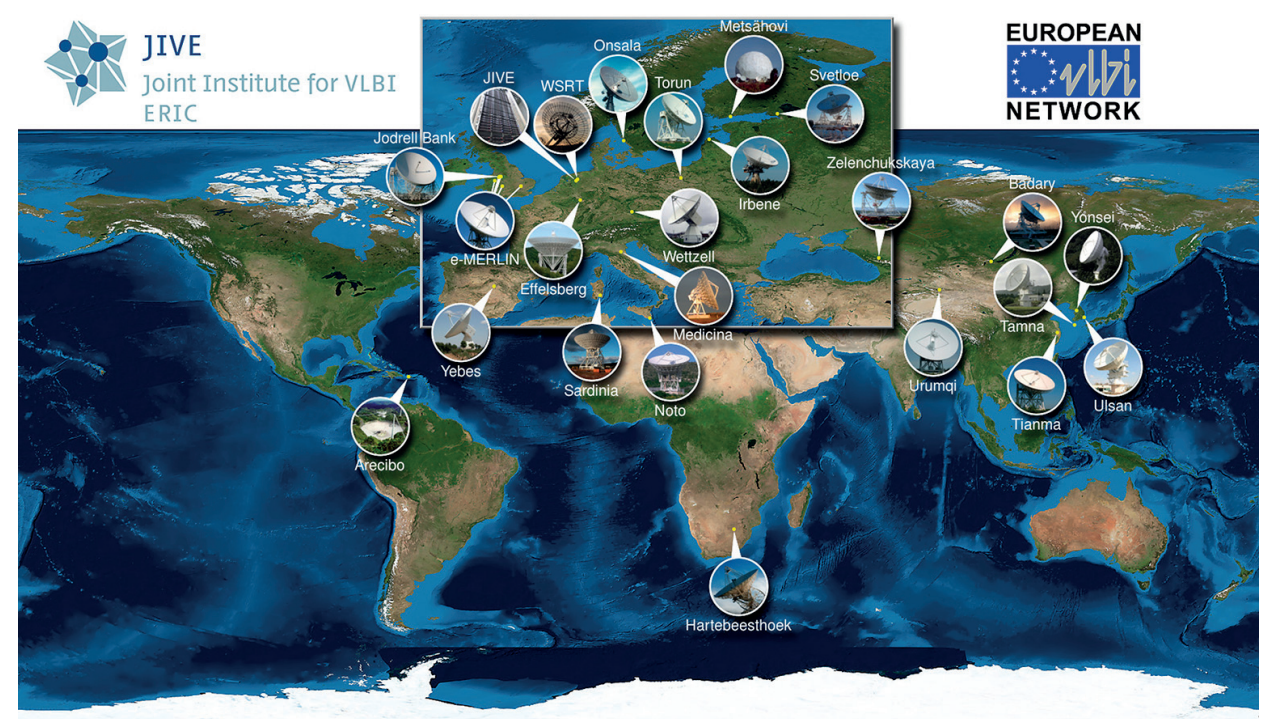

1. ábra. Az Európai VLBI-hálózatban részt vevő antennák (kép: Paul Boven [boven@jive.eu], müholdkép: Blue Marble Next Generation, NASA Visible Earth [visibleearth.nasa.gov]) 
Az ür-VLBI-technikával - ennél a hálózat egyik eleme Föld körüli pályán van a felbontás tovább növelhető. Az első ür-VLBI-célú mühold, a japán HALCA 1997-2003 között végzett megfigyeléseket, többek között a VLBA és az EVN antennáival egy hálózatot alkotva. 2011 óta ủr-VLBI-hálózatot az orosz RadioAstron müholddal valósítottak meg, amely küldetését 2019-ben fejezte be. Elnyúlt ellipszis alakú pályájának földtávolpontja 350 ezer kilométer volt. Így $6 \mathrm{~cm}$-es hullámhosszon a földi hálózatokkal együttmüködve akár 40 milliomod ívmásodperces szögfelbontással is tudott megfigyeléseket végezni.

Viszonylag új, de talán a nagyközönség számára is a legismertebb VLBI-hálózat az Event Horizon Telescope (EHT), amelynek segítségével 2017 áprilisában elöször sikerült megfigyelni egy szupernagy tömegü fekete lyuk körüli árnyék jelenségét. Az adatok feldolgozása és a „képalkotás” több hónapot vett igénybe, végül a fekete lyukról készült képet 2019-ben publikálta a nemzetközi kutatócsapat (lásd még Dálya Gergely tanulmányát e lapszám 902. oldalán). A tudománytörténeti jelentőségú mérést az EHT nyolc elemből álló hálózata végezte (ezek közül a Déli-sarkvidéken található antenna csak a kalibrátorforrás megfigyelésében vett részt). Az EHT egyik részt vevő eleme volt az Atacama Large Millimeter/submillimeter Array (ALMA) interferométer, amelynek több mint ötven antennája egységesen vett részt a megfigyelésben, így biztosítva a szükséges érzékenységet. Az EHT leghosszabb bázisvonala több mint 10 ezer km volt; a mérést $1,3 \mathrm{~mm}$-es hullámhosszon végezték, így az elérhető maximális felbontás 25 milliomod ívmásodperc volt.

A fent felsorolt interferométeres hálózatok - az ALMA kivételével - nyílt rendszerek, azaz bárki adhat be rájuk távcsőidő-kérelmet, amelyeket kizárólag tudományos értékük alapján bírálnak el. (Az ALMA-nál a rendelkezésre álló távcsőidő 90\%-a a müszer építésében pénzügyileg részt vevő partnereket illeti, míg 10\% marad a helyi, chilei csillagászoknak.) Egyébként a VLBI-hálózatok - ideértve az ür-VLBI-t megvalósító hálózatokat is - mindegyike hagyományosan ezt, a teljes mértékben szabadon pályázható felfogást valósítja meg. Néhány esetben kisebb megkötések vannak, például az Ausztráliában müködő hálózatnál (Long Baseline Array) elvárás, hogy a pályázat egyik résztvevője segítsen a helyszínen egy mérés lebonyolításában. A kínai, dél-koreai és japán antennákat összefogó kelet-ázsiai VLBI-hálózatnál pedig erősen ajánlott egy, a müszer müködését jól ismerö, helyi csillagász bevonása a projektbe.

Amikor rádióinterferométerrel végzünk mérést, akkor az égi forrásunk fényességeloszlásának Fourier-transzformáltját, az úgynevezett vizibilitást mérjük (Thompson et al., 2017). A térképezési folyamat lényege, hogy a mért adatokból visszanyerjük a megfigyelt objektum rádióintenzitás-képét (vagy térképét). Elméletileg az eredeti függvény és Fourier-transzformáltja között kölcsönösen egyértelmủ megfeleltetés van, az egyik ismeretében meghatározhatjuk a másikat. Azonban a gyakorlatban létrehozható, valós rádióinterferométer-hálózatunkkal csak bizonyos pontokban tudjuk megmérni a vizibilitásfüggvény értékét (Frey-Mosoni, 2009). Hiába 
áll például az EVN huszonkét antennából, könnyen belátható, hogy nem képes az összes lehetséges irányban és lehetséges bázisvonalhosszal információt adni a mérendő objektumról. Hogy minél pontosabban tudjuk visszaállítani a forrásunk fényességeloszlását, alapvető fontosságú, hogy minél jobb mintavételezést érjünk el a megfigyelés során, azaz minél több pontban mérjük meg a vizibilitást. Ezt egyrészt elösegíthetjük azzal, hogy minél több antennát kötünk be az interferométer-hálózatba, hiszen a lehetséges bázisvonalak száma $N \times(N-1) / 2$, ahol $N$ a részt vevő antennák száma. Másrészt segítségül hívhatjuk a Föld forgását is. Ahogy a Föld elfordul a megfigyelt távoli égi forrásunk ,alatt”, más-más irányból és más-más vetített bázisvonalhosszon tudjuk mintavételezni fényességét. Ez az úgynevezett földforgásszintézis (Earth Rotation Synthesis) technika, amelynek kidolgozásáért Sir Martin Ryle 1974-ben fizikai Nobel-díjat kapott.

A fentiekből az is nyilvánvaló, miért van szükség sok különböző interferométer-hálózatra. Teljesen más „oldaláról” ismerhetjük meg ugyanazt az égi objektumot, ha viszonylag rövidebb bázisvonalakat lehetővé tevő, a nagyobb térbeli szerkezetekre érzékeny müszeregyüttessel vizsgáljuk, amilyen például a VLA, mintha a legfinomabb szögfelbontást megvalósító VLBI-technikát hívjuk segítségül. Ezt a rádiósugárzó aktív galaxismagok példáján keresztül mutatom be.

Az aktív galaxismagok (angol rövidítéssel AGN) központi energiaforrása egy millió-milliárd naptömegü fekete lyuk, amely környezetéből anyagot fog be. A behulló anyag az ún. anyagbefogási korongba rendeződik. Nagyjából minden tizedik AGN-ben a korongra merölegesen, két átellenes irányban nagyenergiás plazmanyalábok, ún. jetek lövellnek ki. Ezekben a rádiósugárzó AGN-ekben a jetekben lévő mágneses tér erővonalai körül a plazma elektromosan töltött részecskei (elektronok, pozitronok stb.) fénysebességhez közeli sebességgel spirális pályán mozognak, és közben az alapvetően rádiótartományban megfigyelhető szinkrotronsugárzást bocsátanak ki.

Relativisztikus vetítési effektusok miatt a különböző látóirányokban megfigyelt rádiósugárzó AGN-ek változatos képet mutathatnak. A rádiógalaxisok esetén a jetek az éggömb érintősíkjához közel helyezkednek el, gyakran figyelhetünk meg nagy kiterjedésű rádiósugárzó nyalábokat, lebenyeket, illetve forró foltokat, ahol a jet a környező galaxisközi vagy csillagközi anyaggal találkozva lelassul, és leadja energiáját. Ezzel szemben az ún. blazárok esetében közel a jet irányából látunk az AGN-re, ezért a felénk haladó jetet fényesebbnek, a tölünk távolodót halványabbnak látjuk a forrás saját rendszerében érvényes szimmetriához képest. Ezért a gyakorlatban a blazároknál csak a hozzánk közeledő jetet tudjuk megfigyelni. A VLBI-technika ideális a blazárok kompakt, fényes kilövelléseinek azonosítására és tanulmányozására, valamint, ha azok megfelelően kompaktak, a kisebb rádiógalaxisok forró foltjait is ki tudja mutatni.

A blazár jelleg kimutathatósága különösen fontos a korai Univerzum vizsgálatakor. Abból, hogy mennyi blazárt ismerünk adott távolságban (adott vöröseltolódás- 
nál), megbecsülhetjük, hogy hány, a látóiránnyal nagyobb szöget bezáró kilövellésủ rádiósugárzó AGN található annál a vöröseltolódásnál. Ezt összehasonlítva a közeli Univerzumban megfigyelhető rádiósugárzó AGN-ekkel, azok kozmológiai fejlődésére utaló jelenségeket vizsgálhatunk. Korábbi mérések felvetették, hogy amikor az Univerzum másfél milliárd évesnél fiatalabb volt (a Világegyetem kora a jelenleg elfogadott kozmológiai modellek szerint közel 13,7 milliárd év), arányaiban jóval több fényes blazárt lehetett megfigyelni (Volonteri et al., 2011). Nemzetközi kutatócsoportunk VLBI-méréseket kezdeményezett, hogy számos nagy vöröseltolódású blazárjelölt forrást vizsgáljon. Három objektumról EVN-mérések alapján meg tudtuk mutatni, hogy nem blazár (Cao et al., 2017; Coppejans et al., 2016). Majd az e-MERLIN-hálózattal azt is felfedtük, hogy ezek viszonylag kicsi, rendre kb. 130, 50 és 20 fényév méretü „bébi rádiógalaxisok” (2. ábra), amelyek különösen fényes forró foltokat tartalmaznak (Gabányi et al., 2019). Eredményünk felveti annak lehetőségét, hogy a más megfigyelési módszerekkel azonosított blazárjelölt források között „,imposztorok” is találhatóak, és rávilágít, hogy a források természetének pontos értelmezéséhez a rádióinterferometria alapvető fontosságú. A jövőben rádióméréseinket felhasználva választ keresünk arra a kérdésre, hogyan téveszthették meg ezek az objektumok a kutatókat, mi lehet az eredete a más hullámhosszakon - jellemzően a röntgentartományban - megfigyelt sugárzásnak, amely alapján blazárjelölt forrásként azonosították öket.

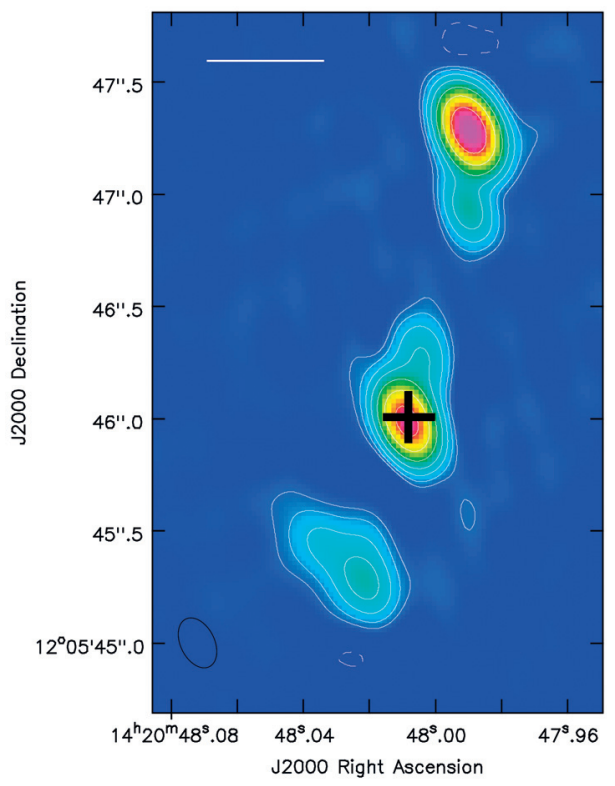

2. ábra. Egy nagy vöröseltolódású rádiógalaxis rádióintenzitás-képe $18 \mathrm{~cm}$-es hullámhosszon az e-MERLIN-nel végzett mérésből. A galaxis középpontját + jelöli. A felső fehér vízszintes vonal kb. 10 fényév méretnek felel meg az égboltra vetítve (Gabányi et al., 2019 alapján) 
A közeljövő legnagyobb rádiócsillagászati fejlesztése a Square Kilometer Array (SKA). Ez az interferométer-hálózat rengeteg kisebb antennából fog állni, amelyek összesített gyüjtőfelülete megközelíti az egy négyzetkilométert. Prototípus modellek már müködnek a két kijelölt helyszínen, Nyugat-Ausztráliában és Dél-Afrikában. Az SKA forradalmasítani fogja a rádiósugárzó objektumokról alkotott képünket, hiszen kimagasló érzékenységével meg fogja sokszorozni az ismert források számát. Az SKA nem lesz nyílt rendszer, a projektben pénzügyileg is részt vevő országok használhatják majd. Szándék van arra, hogy az SKA-t létező, VLBI-t megvalósító hálózatokhoz (például az EVN-hez) kötve is lehessen használni. Kutatócsoportunk nemzetközi kapcsolatai, együttműködő partnerei révén remélhetöleg bekapcsolódhat majd az SKA-val végzendő megfigyelésekbe is.

Munkámat az MTA Bolyai János Kutatási Ösztöndíja és az Új Nemzeti Kiválóság Program keretében (ÚNKP-P-19-4-ELTE-197) az Emberi Erőforrások Minisztériuma támogatta.

\section{IRODALOM}

Cao, H-M. - Frey S. - Gabányi K. É. et al. (2017): VLBI Observations of Four Radio Quasars at z>4: Blazars or Not? Monthly Notices of the Royal Astronomical Society, 467, 950-960. DOI: 10.1093/mnras/stx160, arxiv.org/pdf/1701.04760.pdf

Coppejans, R. - Frey S. - Cseh D. et al. (2016): On the Nature of Bright Compact Radio Sources at z>4.5. Monthly Notices of the Royal Astronomical Society, 463, 3260-3275. DOI: 10.1093/ mnras/stw2236, arxiv.org/pdf/1609.00575.pdf

Frey S. - Mosoni L. (2009): A Short Introduction to Radio Interferometric Image Reconstruction. New Astronomy Reviews, 53, 307-311. DOI: 10.1016/j.newar.2010.07.005

Gabányi K. É. - Frey S. - Paragi Z. et al. (2019): Three Little Radio Galaxies in the Early Universe. Proceedings of Science, EVN2018 Paper: 031. pos.sissa.it/344/031/pdf

Thompson, A. R. - Moran, J. M. - Swenson, G. W. Jr. (eds.) (2017): Interferometry and Synthesis in Radio Astronomy. Springer. DOI: 10.1007/978-3-319-44431-4, link.springer.com/book/10.10 07\%2F978-3-319-44431-4

Volonteri, M. - Haardt, F. - Ghisellini, G. et al. (2011): Blazars in the Early Universe. Monthly Notices of the Royal Astronomical Society, 416, 216-224. DOI: 10.1111/j.1365-2966.2011.19024.x, https://academic.oup.com/mnras/article/416/1/216/1208840 